\title{
The Application of Maqasid Shariah Elements in Family and Marriage Counseling
}

\author{
Mohd Suhadi Mohamed Sidik ${ }^{*}$, Md Noor Saper ${ }^{1}$, Nurul'Ain Mohd Daud ${ }^{2}$ \\ ${ }^{1}$ Universiti Islam Antarabangsa Sultan Abdul Halim Muádzam Shah, Kedah, Malaysia \\ ${ }^{2}$ Universiti pendidikan Sultan Idri, Malaysia \\ ${ }^{*}$ Corresponding author. Email: mohdsuhadimohamedsidik@yahoo.com
}

\begin{abstract}
This paper will present the application of Maqasid Shariah elements in family Counseling and marriage during the decision making process. The qualitative method was employed using the case study approach. The data was collected based on three observations of Counseling sessions and analysed using Model 3C Licthman that involved coding, categorisation and concept. The analysis of the data showed that the application of Maqasid Shariah elements in family and marriage Counseling were implemented by determining the level of need for an action based on the degree of dharuriyyat, hajiyyat and tahsiniyyat and its preservation of five essential elements namely religion, life, intellect, family institution and wealth, specifically in determining the quality of the life and wellness of clients and family holistically so that any decision made will be in the interest of the clients.
\end{abstract}

Keywords: Maqasid shariah, decision-making process, dharuriyyat, hajiyyat, tahsiniyyat

\section{INTRODUCTION}

The marriage between a man and a woman is an undertaking for the couple to perform joint responsibilities according to the role that has been defined in religion. In Islam, every role or regulation that exists in relation to marriage and family affairs functions to safeguard maslahah which involves the family members (Jasser Auda, 2014). Thus, a decision involving the family affairs or a divorce between spouses is critical as any decision will have a major impact on the spouse as well as the nearest family member (Fariz Sakina Abdullah, 2013). This means that a decision can be assessed first on the level of its need because it involves the impact and consequence in life. The level of need in determining an action or decision is divided into three levels or degrees namely, dharuriyyat, hajiyat and tahsiniyyat. Yusuf alQardhawi (2010) has explained that dharuriyyat is a condition whereby if a requirement cannot be fulfilled, then it will cause the destruction to the major aspects of life such as religion, life, intellect, family institution and wealth. On the other hand, hajiyyat is a condition whereby without it, certain aspects may be sustained even though the situation is tough and difficult. As for tahsiniyyat, this is integral for the comfort of life and without it, the situation will not be harmful to the individual.

\section{PROBLEM STATEMENT}

The divorce phenomenon among Muslim couples in Malaysia is increasing and worrying. Statistics from the Department of Sharia Justice regarding divorce among Muslim couples have shown that 156 Muslim couples ended up in divorce on a daily basis from January to August 2015 (KOSMO, January 21st, 2016). According to the source, the causes of divorce among the Muslim couples is due to the lack of mutual understanding, failure in fulfilling the responsibility, family intervention and financial problems.

The Mufti of Penang, Wan Salim Wan Mohd Noor stated that one of the major causes of divorce among young Muslim couples did not understand the actual meaning of maqasid in a marriage (Sinar Harian, March, 21st 2016). Hence, conflicting spouses need to be guided in making decisions in Counseling sessions so that the decisions taken are appropriate and in accordance with the requirements of syarak. An approach which is maqasid shariah oriented involving the use of dharuriyyat, hajiyyat and tahsiniyyat (DHT) applications to safeguard the key aspects of life can be a mechanism in helping clients make appropriate decisions and bring benefit to the worldly life as well as in the hereafter so that the husband, the wife and the family members can achieve holistic well-being. 
The development of particular client approaches and the tendency to choose religious and spiritual elements both in the west and in the Islamic world has demanded that attention be given to religious and spiritual methods in Counseling interventions. This is because conventional methods seemed to have failed to view the decision making process to solve client problems in a holistic manner. According to Graham et al.(2001) the existing approaches are only significant in dealing with the pressure faced by the clients.

In the context of Islamic-oriented religious and spiritual approaches, studies and findings by Islamic scholars in the field of Counseling and psychotherapy only relate to cognitive aspects, the practice of worship in Islam, eliminating the mazmumah characteristics (bad) and changing them with the mahmudah attributes (good). However, there is no study on the application of the maqasid shariah method and the use of dharuriyyat, hajiyyat and tahsniyyat methods in the decision-making process. Critical matters in the process of decision making should take into consideration the maqasid shariah which aims to safeguard the five major elements in life, namely sustaining the key aspects in life.

\section{RESEARCH OBJECTIVE}

The main purpose of this study was to examine the form of DHT applications in the decision- making process in family and marriage Counseling based on selected observations.

\section{LITERATURE OVERVIEW}

Based on a survey on religious and spiritual approaches in domestic and overseas Counseling, it was found that research on it was still limited. In the West, an approach named as a spiritual genogram is used to identify specific religious and spiritual issues to help the client acquire new perspectives on spiritual or religious aspects in making decisions or emulating the practices that have been passed down by the previous generations (Frame, 2000).

This approach has been taken from one of the techniques in the Bowen Family System Therapy introduced by Murray Bowen (1978). The use of spiritual genograms involves four steps that begins with the formation of spiritual genograms, questions for further reflection, relating the genogram to someone in the original family and ultimately, integrating it into the therapeutic session as a whole. By using sketches in this spiritual genograms, clients can look thoroughly on the background of family members regarding attitudes, morals, immoral activities, abuse issues, values, level of appreciation in religion, belief systems and religious rituals that have been carried out in a family.

Religious and spiritual approaches in Islam such as Ad-Din Cognitive introduced by Othman Mohammad (2005), Tazkiyah an-Nafs by Salasiah H. Hamjah (2008) and Modul I-Sc by Md Noor Saper, Nurul Ain
Mohd. Daud \& Norazani Ahmad (2016) as well as others do not focus on family and marriage issues. Based on the existing approaches, there is no approach that explicitly guarantees to safeguard the main aspect of human life such as religion, life, mind, hereditary and property as contained in Maqasid Shariah.

In Islam, the principle of bringing good (maslahah) and avoiding harm (mafsadah) to oneself and others is something that needs to be considered. Al-Shatibi (1996) has explained that maslahah and mafsadah is basically relative (Mahmood Zuhdi, 2012). It may also mean that something that is maslahah and mafsadah in certain circumstances ( or otherwise in other circumstances) may also be considered as not bringing maslahah and mafsadah. According to al-Raisuni (1995), maqasidal-Shariah is a goal determined by Islamic law to be implemented in order to bring good to the servant.

Contemporary Islamic scholars Yusuf al-Qardhawi (2011) and Jasser Auda (2014) concluded that before something is committed, one should look at its potential effects on the main aspects of life, not only to oneself but also to the spouse and other family members. In this regard, they have emphasized the use of the concepts of dharuriyyat, hajiyyat and tahsniyat (DHT) in determining the level of need for an action or decision. Determining the level of DHT needs is inseparable with the aim of safeguarding the main aspects of human life, namely religion, life, mind, family lineage and wealth.

Yusuf al-Qardhawi (2011) stated that the need to evaluate the priorities of an action or decision should be examined as each decision does not only affect the client but also their family members. Therefore, a very important element in making decisions based on the fiqh maqasid syariah is to determine the level of need for certain matters through the mechanism of dharuriyyat, hajiyyat and tahsiniyyat applications. AlShatibi (1996) has explained that maslahah and mafsadah is basically relative (Mahmood Zuhdi, 2012). It may also mean that something which is good or harmful in some circumstances (or otherwise in other circumstances) is considered as not bringing any good or harm. The assessment depends on the situation and it is based on the principle of maslahah and mafsadah which will be the main factor in the dignity transfer of DHT needs. Hence, changes in DHT's dignity can also occur when a particular situation changes, especially those involving maslahah and mafsadah principles.

Asyraf Wajdi Dasuki and Nurdiana Abdullah (2007) in discussing the implementation of the Corporate Social Responsibility (CSR) concept, have pointed out that Islam places great deal of importance on the social interests or the general public as opposed to individual or special group interests. In this respect, Islam has provided a framework or a mechanism in making decisions and making adjustments to particular changes that occur. The management in an organization 
should look at the three levels of considerations when implementing a programme in their corporate activities. Each stage illustrates the different level of importance in fulfilling the social responsibility. The most basic level is the dharuriyyat level which is the most fundamental responsibility to be fulfilled compared to the level of hajiyyat and tahsiniyyat while hajiyyat level is considered more important than the level of tahsiniyyat.

The movement towards the top of the pyramid involves a less fundamental level of responsibility and seeks to achieve a more noble stage and perfection in the aspect of social responsibility that has been done. Assuming that by meeting the requirements at a certain level, one needs to strive to be at a better level than previously.

\section{METHOD}

The data collection was conducted through observation and interviews between the counsellors, the consultants and the clients. The data were recorded in two Counseling sessions. The participants of the study were the counsellor, the consultant and the spouses involved in the Counseling sessions which were conducted at district religious offices and religious agencies which handle Counseling services. The sampling technique of this study is purposive involving a session conducted by the counsellor or the consultant to help the couples to solve their marriage conflict.

The researcher listened to an audio recording of the interview in the relevant Counseling sessions for verbatim writing. The data analysis was conducted using the 3C Data Analysis Method (ThreeC's Of Analysis) which is 'Coding, Categorizing, Concepts' as suggested by Lichtman (2006). This method can help the researcher to understand the conflict and the solution better and to appreciate the meaning that exists to produce the theme of a phenomenon more effectively and accurately.

\subsection{Case Profile 1}

The client, Mrs Mariah (not a real name), had expressed a desire to divorce as she claimed that her husband had caused mental stress to herself and her two children. This meeting was the second individual session after a session between the counsellor, the client and her husband in the previous month. She had been studying for a Master's degree at one of the unversity in the Klang Valley and planned to return with the children to their hometown in Sarawak after the divorce.

\subsection{Case Profile 2}

For the purpose of this study, we will call the second client Mrs Masni. This Counseling session was held without the presence of her husband. However, the husband was present at a session held earlier. In this session, the client intended to apply for divorce from her husband but the tebus talak divorce was difficult for the wife because she had to pay a certain amount to her husband. At the end of the session, the client agreed to hold a meeting with her husband during a Counseling session to be conducted by a conselor.

\subsection{Case Profile 3}

The clients were Mr Rosli and Mrs Nani (not their real names). They had been married for seven years and had two children. The main cause of the conflict was that his wife had lost faith in her husband who had admired another woman and he had been mortgaging jewellery stolen from her mother to pay for the vehicle debt. At the end of the session the couple agreed to take some time especially the wife to rethink the decision to submit the application for a divorce.

\section{FINDINGS}

Based on the analyzed data, it was found that the action was decided based on the determination of the necessity of dharuriyyat, hajiyyat and tahsiniyyat levels, after taking into account the need to safeguard the key aspects in life namely religion, life, mind, family lineage and wealth so that the decisions taken would bring wellness holistically in the world and in he hereafter. Here is the method of determining the levels of need.

\subsection{Determination of Dharuriyyat Requirement Level}

Referring to the observation of Case 1, the researcher found that the aspect of safeguarding of the mind and the life of the wife and children as the dharuriyyat level of need. According to the client, the decision was made as a result of her husband's action when he did not believe her honesty.

Furthermore, the husband as a father to their children had practised autocratic way of life. This situation caused the wife and children to face stress and mental anguish that could cause greater harm to the mind and soul.Therefore, in order to safeguard her interests and those of her children, the wife considered that the decision for a divorce was an action that must be taken so that the risk could be avoided. Clients also assumed that divorce will result in a calm, peaceful state of mind. This can be seen through a client's conversation as follows; 
Client: "I feel depressed by the attitude of my husband who pressured me about the same thing. I didn't do it. I'm not cheating. If I want to cheat, I'll do a long time ago. I can't stand it. With working problem and assignment too. Problems and the affairs of the children again. I am worried I cannot think, I cannot cope anymore. I just want to make a police report. I was worried, when he pressured me, I become tensed and I cannot think." (Source: PK1; 00:11:20,29/9/2016)

As for the observation of Case 2, it was also found that the wellness of the mind involved a degree of the requirement of dharuriyyat. This is because the way the husband treated the client had caused anxiety and emotional disturbances that could have a greater impact on life, mind and dignity of the client. Therefore, the client decided to get a divorce to avoid such risks. In this case, the main thing in the assumption of the client is separation so that the latter could avoid the abuse.

Counselor: "How serious is your need to make a decision for a divorce?Do you think that it is a requirement or is it your emotion and instinct solely?"

Client: : "Just imagine. How can I stay with him if my heart is not for him? How can I become a good wife when I cannot stay with him? That's why I cannot sleep with him. How can he treat me well?"

Counselor: "Divorce is something that is very necessary?"

Client: "Yes. During my life with him, I never felt happy and calm. I also want to be happy and calm. It is not that I need to stay in that problem too. Not like other people."

Counselor: "How do you feel when you are in that situation?"

Client: "I feel pressured. Sometimes when I think, I would suddenly cry. I'm at a loss. I'm scared that I will become insane alone. (Source: PK2 23; 00:19:50, (11/10/2016)

In observation of Case 3, the aspects which have a close relationship with the dharuriyyat category are religion and heredity. The researcher found that among the considerations involved is the appreciation of the children's religious beliefs if the client as the husband and wife separate. Issues relating to the future and the personality of the children are the concern of the husband. He is also concerned about the aspects of religion and the education of his children which might be neglected in the event of the separation. The husband's concern can also be ascertained when his statement raises certain issues over the wife's involvement in various problems and religious failure which will affect the religious aspects of her life. This is illustrated in the following conversation;

Client: "I think about the kids. Why do you want to separate children with their parents? They are growing up. They need love from their parents. What would happen to the children if they separated? There is no love and I'm afraid for my wife. When I am not around, she would go out without wearing hijab, smoking. If we separate, what would happen to her? I don't want her looking for me in the hereafter. I want us to be better, not to turn back into ignorance. I want all of us to go to heaven. I want my children to be good children. Both of my children are males (Source:PK3:00.47; (27/10/2016)

\subsection{Determination of Hajiyyat Requirement Level}

Decisions to be implemented are also based on the determination of hajiyyat requirement level. The matter that can be identified in this level of need is in the aspect of mind and wealth preservation. Referring to the observation made in Case 1 , the process of determining the hajiyyat level can be seen when the client started studying for her Master's degree at an IPTA nearby as a way of relinquishing herself from the pressure of her husband. If the divorce had been finalised, then the study would no longer be a priority. This can be seen through her conversation as follows;

Client: "Actually, I continued my studies because I wanted to get out of this relationship. I don't need him in my life and my children's. I don't want to be tied with him, I want to get out of this hell because I want to go to paradise. Now I'm talking to him, I'm in hell." (Source: PK1 19;00:12:(29/9/2016

In the observation of Case 2 , we ascertain the need to seek income through sewing jobs to cover the daily expenditure, for one's additional income and also for their children. If the husband had been able to provide enough money, there would be no need for the client to find income through the sewing business and so on. This can be seen through the recording of the client's conversation as below; 
Client: "Now I sew. The income from sewing I used to buy daily needs. I don't think he's there for me when I really ask. It's very tiring. When he bought fish, he bought just fish. He never asked if the sugar, salt, turmeric and others things, whether they are available or not." (Source: PK2 23; 00:11:30, (11/10/2016)

Client: "I ask money from him. "Please send RM50.00 to buy goods". He answered. "no need, no need... The red scarf can be used... the scarf can be used." That one I can accept. Because I got the money from sewing job. If the children want to eat, I try to save money from sewing. "(Source:PK2(23);

00:36:40,(11/10/2016)

Client: "After I divorce, it would be alright because I can do the sewing job. After this I will attend a curtain sewing course at Napoh. I don't mind earning my income this way. (Source: PK2 23; 00:37:15, $(11 / 10 / 2016)$

\subsection{Determination of Tahsiniyyat Requirement Level}

The decisions made by the clients had also been identified in the tahsiniyyat stage of the requirement category which is an action to improve or refine the key aspects of life. Based on the observation of Case 1, the researcher observed that the level of tahsiniyyat requirements in this client's case was the extra benefit that could be gained on the mind aspect such as happiness for the client's children if they moved to the village to live with the client's family. This can be seen in his conversation in the following;

Client: "Only my child wants to move. Because I know my child is afraid to stay with his father. My first child asked if she can go to school at Kuching and if possible move there at once. I think my child can think. My second child will follow me. They like the idea because they will be entertained by my dad, my siblings and my mother compared to his dad who does not pay attention. "(Source: PK1 20; 00:14:43(20)29/9/2016

In the observation of Case 2, the aspect of property could be discerned in the client's conversation about his child's suggestion that they move to a convenient place to find a job after the latter's completion of the SPM examination. The need to move had been planned after the divorce with her husband. This opportunity could be used by clients and their children to start a new life and gain employment for them. This could be seen in a recording of the following conversation;

Client: "Yes. The child will be ok. The child once told me; "Mum stays with dad, we are scared to go out. If mum does not stay with dad, we look for another place, we can do the right job. After completing SPM, let's stay somewhere. She cannot stay here because she feels pressured with dad's attitude. She wants to find a job. Looking for my own job too". Emm. I see the condition is better if we parted." (Source: PK2 00:50:15, $(11 / 10 / 2016)$.

In conclusion, based on the data collected from the observations made on the Counseling sessions of Case 1,2 and 3, certain levels of dharuriyyat, hajiyyat and tahsiniyyat requirements could determine the priority in the process of making a decision.

\section{DISCUSSION}

From the foregoing Counseling sessions, the researcher found that different situations required different levels of dharuriyyat, hajiyyat and tahsiniyyat requirements in order to achieve wellness holistically. This is implemented after the client had assessed the cause and effect of a matter in safeguarding the religion, life, mind, family lineage and wealth.

Based on the findings, the level of dharuriyyat requirement is the most important stage compared to the level of hajiyyat and tahsiniyyat requirements. Hence, in the Counseling sessions, Counseling practitioners are required to guide clients to evaluate the pros and cons when taking any action or making any decision. It has been stated by Yusuf al-Qardhawi (2011) that in determining the priority, one should be guided by the evaluation of maslahah and mafsadah as contained in fiqh maqasid syariah. In addition, assessments based on the principles of maslahah and mafsadah would be a major factor in the DHT requirement transfer (H. Said Agil, 1998). Hence, in making any decision or in taking any action one should take the matter or the issue through the process of identifying the levels of dharuriyyat, hajiyyat and tahsiniyyat (DHT) requirements by making the main aspects of life namely religion, life, mind, family lineage and property as the benchmark in determining the logic or the priority of an action or decision. It is also in line with the concepts submitted by al-Shatibi about maslahah and mafsadah when taking action. In Al-Shatibi's view, maslahah is something done to 
safeguard things in the form of achieving goodness and to avoid harm (Mahmood Zuhdi, 2012).

Based on what is suggested by the scholars, when a decision needs to be made, one has to refer to fiqh guidelines or rules first in the preference process. In fact, counsellors or consultants can guide clients to evaluate priorities based on the fiqhiyyah methods which have been debated by many great scholars such as As-Suyuti (2012), Hassan Saleh (1979) and Mahmood Zuhdi (2012).

\section{CONCLUSION}

In summary, to ensure that any action or decision based on this DHT application can be implemented effectively, the family members involved in the conflict must meet in a session to facilitate the process of transformation. In family and marriage Counseling sessions, this restructuring activity is carried out when the family member is in the intuition level. Hence, activities such as evaluating priorities, assessing the advantages and disadvantages of the key aspects of life, transmitting correct information and understanding the level of dharuriyat, hajiyyat and tahsiniyyat requirements have been effectively managed with the guidance from the professional practitioners.

\section{REFERENCES}

Ahmad al-Raisuni. 1995. Nazariyatal-Maqasid 'IndaalImam al-Syatibi, Edisi ke-Empat, al-Dar alAlamiyah Lil Kitab al-Islami, Riyad.

Al-Syatibi, Abu Ishaq. 1996. Al-Muawaqat Fi Usul alShar'yyah, Dar al-Ma'rifah, Beirut.

Asyraf Wajdi Dusuki dan Nurdianawati Irwani Abdullah. 2007. Maqasid As-Shariah, Significance, and Corporate Social Responbility, The American Journal Of Islamic Science. 24:1

Faris Sakina Abdullah. 2013. Penceraian dan Perpisahan. Kementerian Kesihatan Malaysia, Diaskses dari http://www.myhealth.gov.my/index.php/pencera ian-dan-perpisahan pada 14 Nov 2014

Frame, M. W. 2000. The spiritual genogram in family therapy, Journal of Marital and Family Therapy University of Colorado at Denver. April 2000,Vol. 26, No. 2,211-216

Graham, S., Furr, S., Flowers, C. \& Burke, M.T. 2001. Religion and spirituality in coping with stress [Electronic version]. Counseling and Values, 46(1), 2-14.

Hassan Saleh. 1979. Al-Qawaid Al-Fiqhiyah (PrinsipPrinsip Fiqh Islam), Universiti Kebangsaan Malaysia. Kota Bharu Pustaka Aman Press.

JAKIM. 2015. Indeks Syariah Malaysia. Model Tadbir Urus Berteraskan Maqasid Syariah. Penerbit Jabatan Kemajuan Islam Malasyia. Putrajaya
Jalaluddin Abdul Rahman As-Suyuti. 2012. Kaedah Usul Fiqh Imam Syafi'i: Al-Asybah Wan Nadhair. Terjemahan Abu Ezzat al-Mubarak. Perniagaan Jahabersa, Johor Baharu

Jasser Auda. 2014. Memahami Maqasid Syariah. Peranan Maqasid Dalam Pembaharuan Islam Kontemporari. PTS Publication

Lichtman, Marilyn. 2006. Qualitative Research in Education. A User's Guide, Sage Publications Inc. California

Lichtman, Marilyn. 2010. Qualitative Research in Education. A User's Guide, 2nd Edition. Sage Publications Inc. California

Mahmood Zuhdi Abdul Majid, Mek Wok Mahmud, Akhtar zaite Abdul Aziz. 2012. Maqasid AlSyariah, IIUM Press, IIUM Printing Sdn Bhd. Batu Caves, Selangor.

Md Noor Saper, Nurul Ain Mohd. Daud \& Norazani Ahmad. 2016. Kesahan Dan Kebolehpercayaan Modul I-Sc (Islamic Spiritual Counseling) Ke Atas Pelajar Bermasalah Tingkah Laku. International Journal of Islamic Thought. Vol. 9: (June) 2016

Othman $\mathrm{Hj}$. Mohamed. 2005. Prinsip Psikoterapi dan Pengurusan Dalam Kaunseling, edisi ke-2. Serdang: Penerbit Universiti Putra Malaysia.

Othman Lebar. 2014. Penyelidikan Kualitatif: Pengenalan Kepada Teori Dan Metode. Penerbit Universiti Pendidikan Sultan Idris. Tanjung Malim. Perak

Salasiah Hanin Hamjah \& Noor Shakirah Mat Akhir. 2014. Islamic Approach in Counseling. Journal of Religion and Health 53 (1): 279-289.

Salasiah Hanin Hamjah, Muhammad Adib Samsudin, Raja Nor Asmani Raja Yaakob, Izzah Nur Aida ZurRaffar, NoorAmila Abdul Halim \&Rosmawati Muhammad Rasit. 2016. Tinjauan Awal Gaya Hidup dan Amalan Spiritual dalam Kalangan Profesional Muslim. Prosiding Seminar Kebangsaan Tamadun \& Warisan Islam (TAWIS) 2016

Salasiah Hanin Hamjah, Zainab Ismail \& Noor Shakirah Mat Akhir. 2012. Kaedah Penerapan Ibadah dalam Kaunseling. Jurnal Teknologi (Social Sciences) 59 (1): 87-92.

Yusuf al-Qardawi. 2011. Fiqh Keutamaan (Fiqhul Aulawiyyat). Perniagaan Jahabersha, Johor Baharu. Johor Darul Takzim 